\title{
User-based Design of Campus Pedestrian: Case Study - Universitas Negeri Medan
}

\author{
$1^{\text {st }}$ Irma Novrianty Nasution, $2^{\text {nd }}$ Rumilla Harahap ${ }^{2}, 3^{\text {rd }}$ Zulfikar Ahmad ${ }^{3}$ \\ \{irmanasution@unimed.ac.id ${ }^{1}$, rumillaharahap@unimed.ac.id ${ }^{2}$, ahmadzulfikar@unimed.ac.id ${ }^{3}$ \} \\ Universitas Negeri Medan, Jalan Darusalam/Abdi No.11 Medan - 20119 1,2,3
}

\begin{abstract}
The "Green Campus" ranking awarded by the UI Green Metric to the Universitas Negeri Medan should be a trigger for the campus to improve and maintain the ranking. The users of campus transportation, such as walking and driving, is one of the targets set as a ranking indicator. However, this facility has not met the design and user feasibility aspects, especially at the entrance points of the campus to other buildings. The purpose of study to examine the factors from the user and existing pedestrian as a basis for decision making in the design process. Research variables include user aspects, activities and dimensions, accessibility, safety, health, clarity, and aesthetics. This study uses a survey method with quantitative and qualitative research types, while in data analysis using descriptive statistics. Primary data obtained from field observations based on pedestrian design standards. Secondary data obtained from the distribution of online questionnaires with closed-ended questions to a number of samples, namely the academic community. In the end, the design concept is prepared based on user needs and the resulting design is expected to be a benchmark for the campus in improving internal transportation.
\end{abstract}

Keywords: Pedestrian, campus, user-based, Universitas Negeri Medan.

\section{Introduction}

The planning design of the campus area should consider the user as the main factor in the design process. Universitas Negeri Medan (Unimed) campus area is facilitated by internal transportation routes that are specifically for users by walking or driving. Based on data from PDDikti in 2020, there were 26279 students and 984 lecturers, as well as 561 educators who use the campus area every day [1]. Based on observations, $90 \%$ of the total lecturers use vehicles, cars or motorbikes, to access all campus facilities. 50\% of the number of students and education staff who use vehicles, motorbikes or bicycles, and the rest use pedestrian platform to access campus facilities. In certain activities such as graduations, festivals or exhibitions, and other social events, pedestrian is a platform used by visitors outside the academic community.

As Unimed has been named a green campus in the 20th ranking of the top 25 universities in Indonesia and is the only university that is included in the UI Green Metric in North Sumatra [2]. The purpose of UI Green Metric is to provide a ranking of universities in environmental management. The goal is to create a healthy campus environment with several indicators, including; campus greenery, waste management, energy and climate change, water use, transportation, and education. Unimed should improve itself to be able to improve the 
management of campus infrastructure in the future in the form of policies or pedestrianoriented facility designs. This is an effort to encourage the realization of a campus that is more humanistic and environmentally friendly. The dispersed character of the Unimed campus area requires special routes that are comfortable and safe, such as corridors between buildings and other facilities intended for pedestrians.

According to research from Stanford University, Indonesian people have an average walking activity level of 3,513 steps per day [3]. Factors that influence, among others, pedestrian platform that are not feasible (narrow, perforated, do not meet the standards, the selection of materials that are not appropriate), are taken over into other functions and do not reach all areas of the city [4]. There are four important factors that are considered and affect the length or distance of people walking, including time, comfort, availability of vehicles, and land use patterns [5]. The main consideration for platform is the balance of interaction between pedestrians. feet and vehicles, safety factors, sufficient space for pedestrians, facilities that offer pleasure along the pedestrian area, and the availability of public facilities that are integrated and become supporting elements [6].

Currently, Unimed pedestrians have not been designed based on considerations of comfort, safety, and adequate interaction in public spaces. The platform problems can be identified from the selection of inappropriate materials, the width of the platform does not follow the standards of human movement, the footing is quite high, it is located on the edge of an open drain, blocked by other buildings, without shelter, no stopping facilities, not integrated with other public facilities, does not provide pleasure and interaction between other users. Based on observations, the academic community is less interested in using pedestrians platform. Once upon a time, users preferred to walk on the road and not on the platform.

The phenomenon of the Unimed campus pedestrians platform is an interesting to study. Looking at the factors that influence users do not choose to walk, but prefer to use vehicles to move from one place to another within the campus. Consideration of user factors can be used as a basis in making design decisions, especially the main things regarding humanist and contextual design criteria. Therefore, proper and functional pedestrian arrangement that can accommodate all pedestrian activities must be carefully considered based on the needs of its users.

\section{Theory}

Pedestrian is the movement or circulation of the movement of humans or users from one place of origin to their destination on foot. A road segment needs to be equipped with a pedestrian platform if along the road there is land use that has the potential to cause pedestrians [7]. Pedestrian ways function as a place or space for pedestrians to carry out activities and provide services so as to improve the smoothness, safety, and comfort for them. Pedestrian development is not only for pedestrian ways but also for recreational activities, such as sitting back and enjoying the city atmosphere, to socialize and communicate between residents [8].

The platform is equipped with street furniture or elements. Its function is to protect pedestrian activities by creating a sense of security and comfort. Elements of the platform include the following [9]:

a. Material elements that are generally used on pedestrian platforms are paving (concrete) or stone. 
b. lights, namely low-level lights (height below the human eye), mall lights (height $1-1.5 \mathrm{~m}$ ), special lights (height 2-3m), parking and road lights (height $3-5 \mathrm{~m}$ ), and high pole lights (height $6-10 \mathrm{~m}$ ).

c. Signages are signs that serve to provide a sign, be it information or prohibitions. Signage must be easy to see with the human eye's distance and the image must be contrasting and not cause glare.

d. Sculpture, made to beautify pedestrian platforms or attract the eye (vocal point), is usually located in the middle or in front of the plaza. Sculpture can be in the form of a statue, a fountain or abstract.

e. Bollards are barriers between pedestrian platforms and vehicle lanes. Usually used in conjunction with laying lamps.

f. Bench, has a function as a place to rest for road users. Also gives time for pedestrians to enjoy the atmosphere of the surrounding environment. Benches can be made of metal, wood, concrete or stone.

g. Shade plants, have the function of protecting and cooling the pedestrian area. So that the shade plants must have good resistance to weather and dense leaves.

h. Kiosks, shelters, and canopies, their existence is able to liven up the atmosphere on the platform so that it is not monotonous.

i. Trash cans are placed on the platform so that the path remains clean so that pedestrian comfort is maintained. Trash cans are placed on the amenity track. Located every $20 \mathrm{~m}$ with a size as needed, and the materials used are materials with high durability such as metal and concrete.

The requirements for designing pedestrian platform in order to create a good platforms are as follows [10]:

a. Pedestrian surface conditions: must be strong, stable, flat and not slippery; The materials that are usually used are paving blocks, bricks, concrete, brick, natural stone, or a combination of the aforementioned.

b. Conditions of resting areas: should be made at certain distances and adjusted to the scale of walking comfort distance; usually about $180 \mathrm{~m}$ away.

c. Size of the ramp (ramp): a ramp with a slope below $5 \%$ for public pedestrians; a ramp with a slope of up to $3 \%$ is more practical to use; ramps with a slope of $4 \%$ to $5 \%$ must have a distance of about $165 \mathrm{~cm}$; ramps with slopes above $5 \%$ require a special design.

d. Pedestrian dimensions: Pedestrian dimensions based on the number of road directions: minimum width of about $122 \mathrm{~cm}$ for one-way roads; a minimum width of about $165 \mathrm{~cm}$ for a two-way street.

e. Pedestrian dimensions based on road class: class 1 road, road width $20 \mathrm{~m}$, pedestrian width $7 \mathrm{~m}$; class 2 roads, $15 \mathrm{~m}$ wide, $3.5 \mathrm{~m}$ wide for pedestrians; class 3 roads, $10 \mathrm{~m}$ wide, $2 \mathrm{~m}$ wide for pedestrians.

f. Dimensions of pedestrians based on the area or environment: shopping environment, pedestrian width of $5 \mathrm{~m}$; office environment, width of $3.5 \mathrm{~m}$; residential environment, width of $3 \mathrm{~m}$.

g. Lighting system and protection against sunlight: lighting at night along the platform the minimum power used is 75 Watt; Protection against sunlight can be done by planting shade plants at a certain distance. 
h. Maintenance system: cleaning of pedestrians and elements therein; garbage transport; replacement of materials and elements that are no longer suitable for use; watering plants; fertilizing plants; plant pruning.

i. The condition of the drainage structure must pay attention to the direction of the slope, whose function is to help drain rainwater that may stagnate.

j. Roadside conditions Roadsides are required not to exceed the maximum height of one foot, which is about $15 \mathrm{~cm}$ to $16.5 \mathrm{~cm}$.

k. Boundary walls: the dividing wall with seating should have a height of about $45 \mathrm{~cm}$ to 55 $\mathrm{cm}$ and a minimum width of $20 \mathrm{~cm}$ to be able to sit comfortably on it; a low dividing wall, measuring between $66 \mathrm{~cm}$ and $99 \mathrm{~cm}$, which can be used to lean on a sitting position or to sit on it; transparent walls, such as bamboo/wood, trees, shrubs and pseudo walls formed from river water boundaries, horizons can also be used as a barrier for platform with vehicle lanes, each of which has varying heights.

1. Condition of the crossroads area: signage needs to be equipped to help pedestrian users carry out their activities such as crossing; signage, especially traffic signs, should be designed not to be blinding, easy to see and placed at a height of about 2 meters; designed to emphasize the location of pedestrian crossings, which must be easily seen by vehicle drivers and pedestrian users; using textured materials to describe the shape and boundaries of platform; the signage used should have a dark background with brightly colored letters; It is recommended that the inside width of the crossing is the same as the width of the adjacent road.

A pedestrian platform is a path intended for walking. It can be in the form of sidewalks, level crossings (zebra crossings or pelican crossings), and non-level crossings (bridge crossings and tunnels) [11]. Good planning and design of platform will support the activities carried out by their users safely and comfortably. Platforms are also a space for humans to carry out activities such as shopping, interacting, and become a characteristic of an environment [12]. The development of facilities for platform is security, safety and improvement of the image of the physical system to increase comfort, safety, pleasure, sustainability, completeness and attractiveness [13]. There are several things that can be used as indicators of achieving a familiar pedestrian facility development concept, as follows:

a. safety, realized by the placement of pedestrians, structures, textures, pavement patterns and dimensions of platform (free space, effective width, slope);

b. security, protected from the possibility of criminal acts taking place by designing adequate lighting or structures or landscapes that do not obstruct;

c. comfort, easy access from various places with protection from bad weather, temporary resting place, protected from obstacles due to narrow space and a surface that must be comfortable to use by anyone, including people with disabilities;

d. enjoyment, indicated by distance, width of platform, attractive landscape and proximity to required facilities; beauty (aesthetic), related to the platform and the surrounding environment.

\section{Methodology}

The research approach is descriptive qualitative. Qualitative research is to observe the platform as the object of research to obtain primary data. Descriptive research is to describe 
existing condition of the Unimed Campus pedestrian ways and collaborate with a literature review on the theory of the technical requirements of the platform. The scope of the research is the pedestrian ways in the Unimed campus area with a study variables approach to the platform. Determination of research variables is used to obtain information about the design requirements of platform to obtain conclusions.

Data collection is done through primary and secondary. Primary data were obtained from observations, while secondary data were in the form of a map of the Unimed and the results of a literature review. Other secondary data was obtained from distributing questionnaires aimed at obtaining data in the form of user responses to the existing platform. The object of research is the platform inside the campus area. The sample for the questionnaire is the academic community, including students, lecturers, and education staff as direct users of the pedestrian.

Data that obtained through observation and questionnaires will be analyzed systematically. The data that has been compiled then compared with the theories in the literature review to obtain precise and easy-to-understand information. The analysis carried out in this study is related to the pedestrian condition based on the standards and regulations that apply to campus pedestrian platform.

\section{Discussions and Results}

\subsection{Universitas Negeri Medan campus Pedestrian Profile}

Unimed is one of the State Universities in North Sumatra with educational and noneducational programs. Environmentally, the campus is located in an integrated area equipped with infrastructure in the form of a lecture hall, multipurpose building, departmental offices and the rector's bureau, sports facilities, open spaces, as well as internal transportation facilities, namely roads, pedestrians, and parking lots. The campus is located in Percut Sei Tuan District, Medan City, precisely on Jalan Willem Iskandar Pasar V. The boundaries of the dictionary are as follows:

North side : Jalan Peratun

To the East : Belawan-Medan-Tanjung Morawa Green Toll Line

South side : Jalan Willem Iskandar Pasar V

West side : Jalan Selamat Ketaren

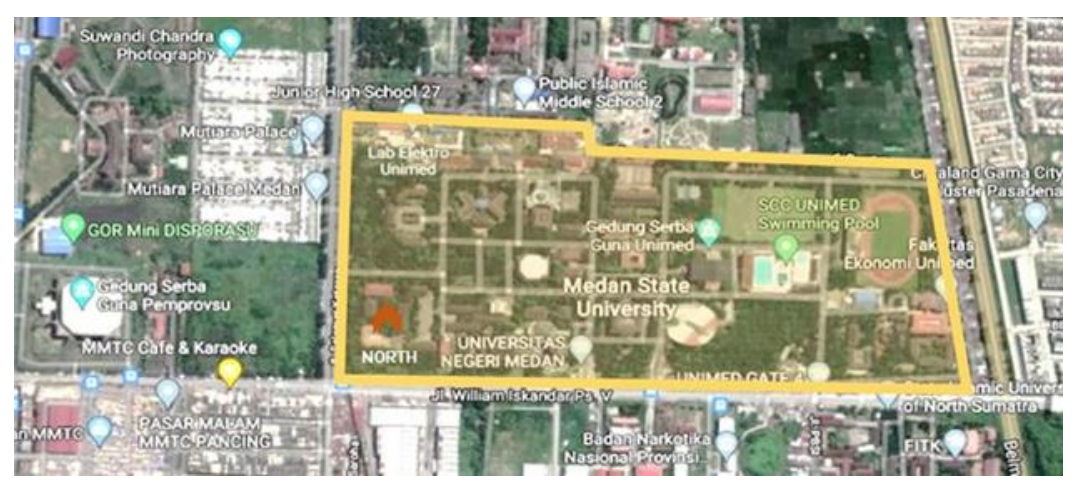

Fig. 1. Universitas Negeri Medan campus location. 
The central neighborhood of a campus is where the main campus buildings are located. The main campus buildings include a library, rectorate building, canteen, student activity center building, sports hall, multipurpose building, and auditorium. The campus environment is an important campus area and a center for academic community activities. The campus arrangement is integrated between the central and supporting areas that is designed to follow a grid form.

In addition, the campus environment is equipped with large open spaces and is planted with shady trees, so that the campus atmosphere is beautiful and shady. However, open space is only limited to green area and has not been utilized as a public space that can preserve interaction between campus residents. The discussion facilities for students in open spaces have not been specially facilitated and designed. The roads in the area are quite good with asphalt concrete pavement systems and pedestrians are designed only as a complement. This is evidenced by the selection of materials, dimensions, and designs that have not consider the technical standards. Disadvantages of pedestrian arrangement include slippery pavement surfaces and the selection of the wrong type of material. Based on observations, the platform do not have the same dimensions from one part to another. While the height and slope of the platform is not considered to avoid accidents when walking. In form, there are several errors, including platform not having clear stops, there is a building in the middle of the platform, electricity poles and lights in the middle of platform, platform that are cut off, especially at the entrance to the campus area, and there is no clear path from platform to buildings and others facilities.

Overall, the campus's internal transportation system does not cause density except at certain times and activities. Density occurs at the exit and entry points of the campus area due to the mixing of pedestrian and vehicle lanes. This condition sometimes causes motorists to violate driving rules and the intensity of pedestrians on the platform becomes low.

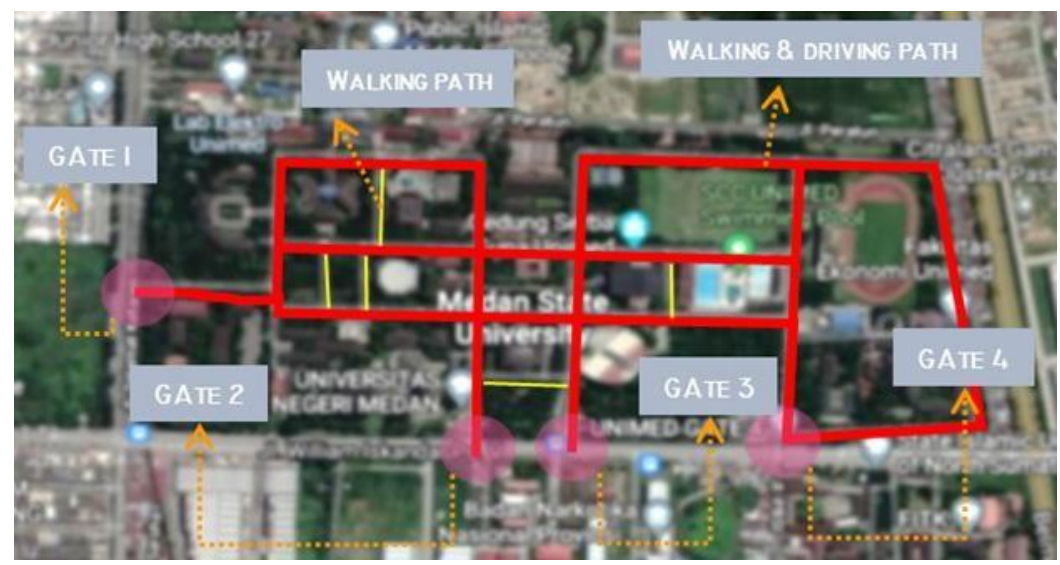

Fig. 2. Accessibility entrance to the campus area.

\subsection{Human and activities}

Activities on pedestrians are very dependent on human movement. Based on observations, Unimed campus pedestrians have not been used optimally as internal transportation facilities. This is supported by the results of a questionnaire which shows the intensity of pedestrian use by $55 \%$ of the 150 respondents who rarely use the platform. 
Platforms are used by pedestrians in pairs and groups it means that pedestrians can become the center of activity and or interaction of the academic community in public open spaces. The main reasons why users walk on campus pedestrians include a friendly and comfortable environment, healthy, being able to interact with other people, and habit factors. From these reasons, it shows that the academic community does not yet have a habit of using campus pedestrians, which is only $23.9 \%$ of the total number of respondents. Based on it, Unimed pedestrians need to be rearranged to increase activities in public open spaces and the benefits of integrated campus internal transportation routes.

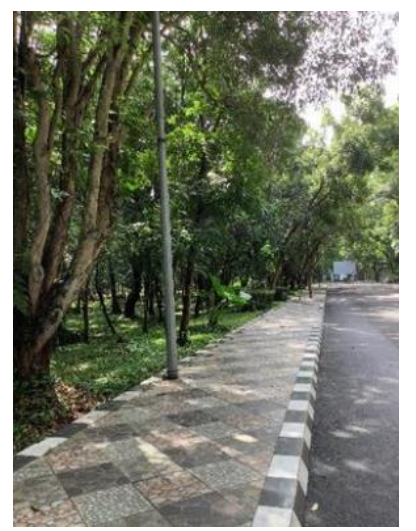

Fig. 3. Pedestrian activities are not barrier-free.

\subsection{Dimensions and Accessibility}

Dimensions of the platform are the distance and territory of human movement in carrying out activities on the pedestrian. Dimensions can be identified from the distance of the movement space according to the width of the body and the height of the platform, as well as the slope of the platform surface. Design of the platform dimensions is measured based on the analysis of human activities that occur on the platform. Walking is the main activity on the platform. Pedestrian movement space is determined from the pattern of trips carried out individually, in pairs, and in groups. The type of user also affects the dimensions and character of the platform surface such as general and special users, i.e. people with special needs. People with special needs of course need assistive devices to travel or move on the platform.

The characteristics of platform users on the Unimed campus are generally walking, sitting relaxed and discussing, as well as meeting places. $92.9 \%$ of respondents stated that walking is the dominant activity on the platform. According to the respondent's statement, the dimensions of width and height are sufficient to be passed individually or in pairs. The width of the lane varies, namely $120 \mathrm{~cm}, 154 \mathrm{~cm}$, and $210 \mathrm{~cm}$. The height of the path from the front of the road is 3 to $4 \mathrm{~cm}, 20 \mathrm{~cm}, 26 \mathrm{~cm}$, and $40 \mathrm{~cm}$. Platforms must have free space, i.e. free areas from distractions or obstructions. The minimum free height dimensions are $2.5 \mathrm{~m}$, the free depth is at least $1 \mathrm{~m}$, and side freedom is $0.3 \mathrm{~m}$. The effective width of the platform is at least $2 \mathrm{~m}$ according to the minimum width limit for land use in the school area [14]. In addition, the platform surface must be flat and have a transverse slope of 2 to $4 \%$. The longitudinal slope can be adjusted to the maximum longitudinal slope of the road by $10 \%$, so that there is no puddle of water. Technically, the width of the Unimed campus platform has met the minimum 
design criteria for pair walking activities, but it needs to be re-planned according to the needs analysis and other activities that may develop on the pedestrian by taking into account the minimum provisions.

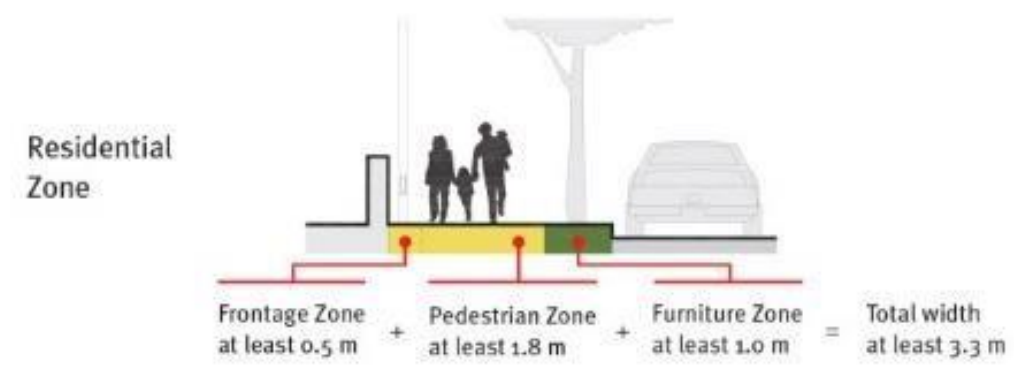

Fig. 4. Minimum width of the pedestrian based on Indian Roads Standards [15].

Based on users, pedestrians are easily accessible from the entrance of the area directly. Based on observations, there is no direct access from campus to public platform. This access is cut off and blocked by the campus gate so that pedestrians must first pass through the main road and then through the platform to the buildings within the campus area (see Fig.5.). The Planning is not integrated between campus and off-campus areas which is create a bad culture for the pedestrians and needs improvement in the future.
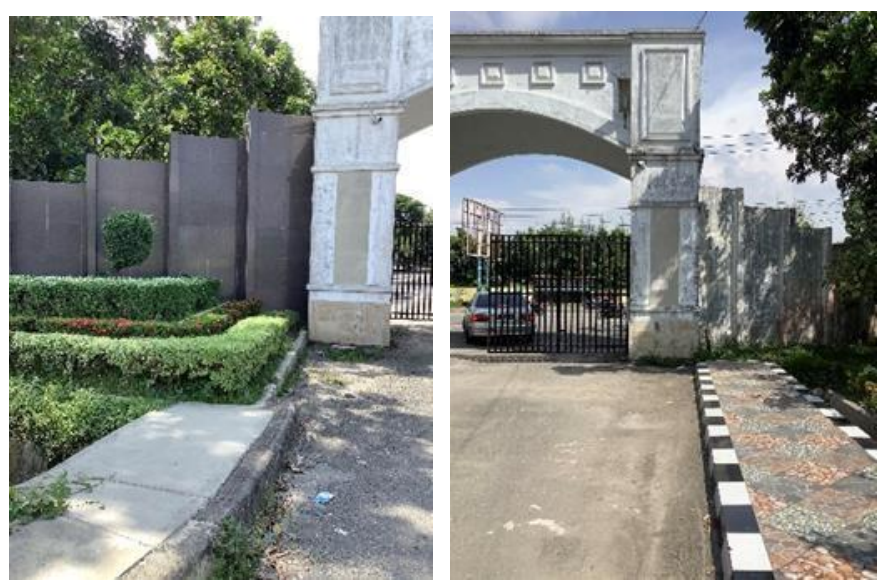

Fig. 5. Pedestrians access is cut off between campus and public pedestrian platform.

The campus area can be accessed from 4 main entrance gates (see Fig.2.). 58.6\% of respondents stated that the distance from the entrance gate to the destination on campus was close, namely less than 100 meters. This means that the distance from the main gate to the location of the campus buildings is adequate for pedestrians. The daytime conditions are quite hot and at some points the pedestrians are not overgrown with shady plants, it is possible to rearrange the platform that are pleasant and comfortable for pedestrian activities. The current lines are not all well connected. At several points on the platform, there are paths that are cut off with the condition of the width of the lanes not matching each other, paths that are blocked 
by other buildings and electricity poles, access to the location of buildings is cut off and blocked by sewer walls, and there is no clear stop at the end of the lane. In addition, it is necessary to create a platform that is easily accessible without driving a vehicle in various weather conditions.
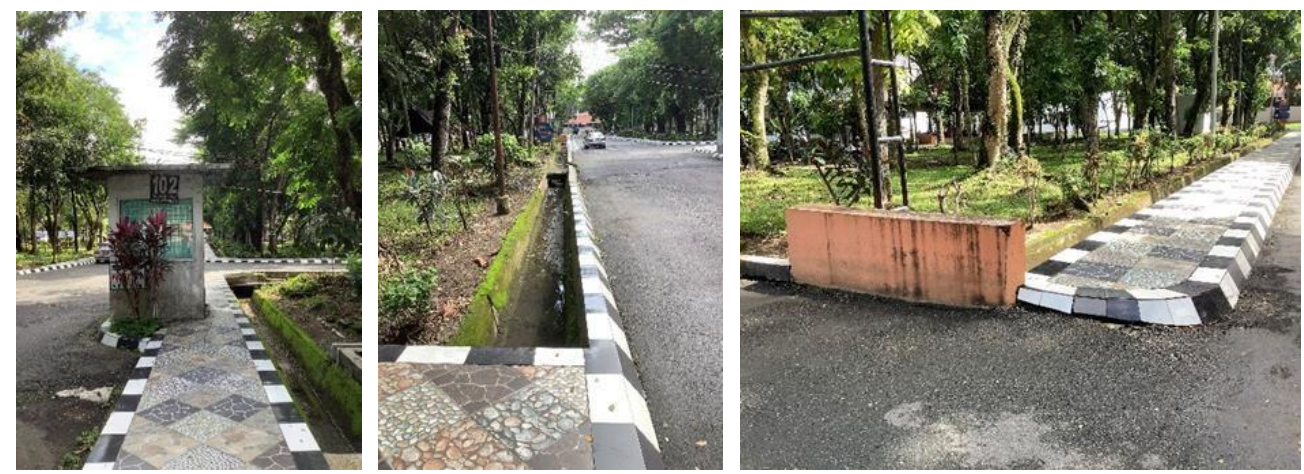

Fig. 6. The platform conditions do not follow design standards requirements.

\subsection{Healthy and safety}

The location of the platform based on questionnaire and observations is good enough in the safe category to accommodate pedestrian activities. The movement of pedestrians from one lane to another is quite clear and the platform is protected from the vehicles lanes. The width of the lane does not interfere with the circulation of other pedestrians when passing, stopping, and interacting. Based on observations, it found broken lines with various widths and discontinuous locations. The platform does not have a sloping concept for access to the main and supporting building locations. Slopes are also not found on the crossing path used by pedestrians to reach certain buildings, for example the platform in front of the Rector's bureau, library, and multipurpose building. There are pedestrian movements on the platform that are free without obstruction and some are blocked by electric poles and lighting lamps, pedestrian signs, and water hydrants. The surface of the platform and curb uses a slippery textured material when it rains, so it is necessary to consider accommodating various outside conditions so that pedestrians do not slip. The position of the platform near to an open drain is quite vulnerable to pedestrian safety. The dimensions of the platform level from the road surface being 20 to $40 \mathrm{~cm}$, while the minimum standard is $7.5 \mathrm{~cm}$ and the maximum is $10 \mathrm{~cm}$. Throughout the platform there are no stops, trash cans, bench, and shade plants at a certain distance to maintain the comfort and cleanliness of the environment around the platform. Based on the platform design criteria, every $20 \mathrm{~m}$ distance, at the intersections it is necessary to place trash bins, bench, and shade plants. 

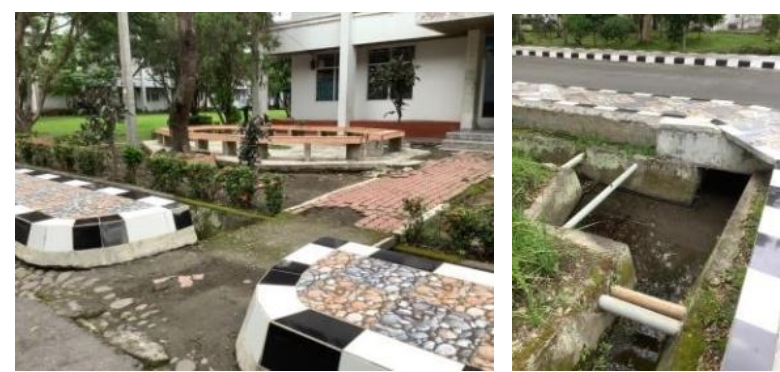

Fig. 7. Pedestrian safety level is seen from the condition of the level height and the proximity of the open drain.

\subsection{Aesthethics and clarity}

The clarity of the platform can be observed from the continuity of it access to the building, the difference between pedestrian and vehicles lanes, ramps, and the guide lane for disabilities. The existing condition of the platform indicates that there is no continuous access from the platform to the building. When the weather conditions are rainy, pedestrians cannot reach the building smoothly. Therefore, it is necessary to have clear access to buildings that can accommodate weather conditions for the smooth passage of pedestrians. Pedestrian and vehicles lanes separation is clear but the distance is too close, there is no barrier to maintain the safety of pedestrian activities. The barrier can be bollards or shade line is placed along the platform. The requirements for the bollards location are about $30 \mathrm{~cm}$ from the curb, with a diameter of $30 \mathrm{~cm}$ and a height of $0.6-1.2 \mathrm{~m}$, and a placement distance of no more than $1.4 \mathrm{~m}$ [16]. Arrangements for access to buildings are arranged with the aim of reducing conflicts between pedestrians and vehicles, providing access for pedestrians, and increasing visibility between vehicles and pedestrians in driveways. There are three ways to determine the arrangement of the driveway, which can be done by: 1) vertical curb ramps; 2) combination curb ramps; and 3) parallel curb ramps. Guide lanes are used using tiles or distinguishing blocks and have 2 types, namely dome shaped blocks and lines. Placement along the platform, the end of the platform, and on the path that connects the road and building. The guide tiles should have about $600 \mathrm{~mm}$ of free space on the left and right of the tile, and the arrangement of line tiles should be as straight as possible for pedestrians to follow.

Table 1. Entrance design elements [17].

\begin{tabular}{|l|l|l|}
\hline \multirow{2}{*}{ Elements } & \multicolumn{1}{|c|}{ Main Issue } & \multicolumn{1}{|c|}{ Additional information } \\
\hline Ramp & Maximum longitudinal slope 12\% (1:8) & $\begin{array}{l}\text { Longitudinal slope recommended } 8 \% \\
(1: 12)\end{array}$ \\
\hline & $\begin{array}{l}\text { Maximum transverse slope 2\%(1:50) } \\
\text { Minimum width } 1.2 \mathrm{~m}\end{array}$ & Maximum transverse slope 2\%(1:50) \\
\hline & Guide tiles & Recommended $1.5 \mathrm{~m}$ \\
\hline
\end{tabular}




\begin{tabular}{|l|l|l|}
\hline Landing & $\begin{array}{l}\text { Maximum transverse and longitudinal } \\
\text { slope 2\% }(1: 50\end{array}$ & $\begin{array}{l}\text { To prevent wheelchair users from losing } \\
\text { balance, or rolling } \\
\text { Minimum width } 1.2 \mathrm{~m}\end{array}$ \\
\hline
\end{tabular}

The campus pedestrian platform is long enough to pass without any stops for users to rest. Platforms are not designed to achieve aesthetic value. The atmosphere of a green campus environment with tall and shady trees is quite comfortable but not for walking activities. The form of the platform is monotonous so it is not attractive to pedestrians. Based on the results of the questionnaire, the pedestrian arrangement of the Unimed campus was tiring and tedious, only able to accommodate walking activities, and not equipped with recreational facilities (benchs, plazas, kiosks). The most significant is it necessary to rearrange the platform which is equipped with a link corridor and shelter to the building area, as well as a plaza design along the platform with a certain distance that functions as a generator of motion and interaction in open spaces. So far, students have been doing a lot of activities in public open spaces near the pedestrian area but there are no good facilities and clear access to these areas. Therefore, it is necessary to design interaction facilities for students in a public space and it close to the pedestrian area as the main access.
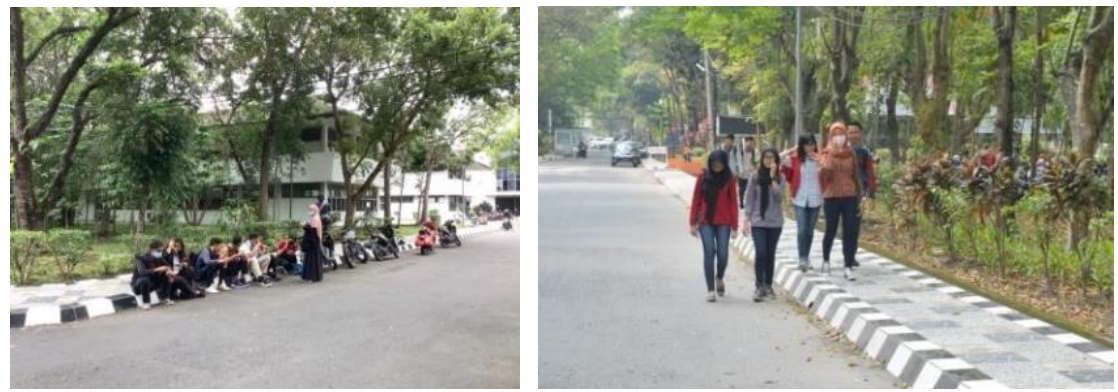

Fig. 8. Pedestrians are not only used as walking paths but also to interact with each other such as sitting.

\section{Conclusion}

The results of questionnaires and observations of pedestrian in the Unimed campus indicate that users need a platform that are able to accommodate walking activities and interactions in open spaces comfortably. The existing pedestrian design does not meet the standarts requirements of the platform and has not been used optimally.

In theory of pedestrian design, the user is the main factor in determining the design direction. Therefore, the design approach must consider pedestrians as the main users who are not only functioned as circulation paths but furthermore as activity spaces in public open spaces. To maintain the "green campus" ranking, Unimed should improve, especially in the arrangement of the area, in this case the pedestrian, as a center of activity and movement of the academic community in public spaces. So the Unimed campus pedestrian needs to be reorganized as a functional and attractive for users. 
Acknowledgments. The authors are grateful to the LPPM Universitas Negeri Medan, who has funded the paper to attending this conference, who has provided opportunities for lecturers to participate in various research schemes to expand and develop scientific insights.

\section{Reference}

[1] PDDikti. Pangkalan Data Pendidikan Tinggi. Available from https://pddikti.kemdikbud.go.id/data_pt/RkE4M0E5RkYtNzRCMi00OTM4LTg1 NEEtMEY0OTE1RDVBNDFE. [Accessed $12^{\text {th }}$ July 2021].

[2] Tribun Medan. Unimed Peningkat 20 Kampus Hijau Satu-Satunya di Sumut. Available from http://gnews.online/unimed-peringkat-20-kampus-hijau-satu-satunya-di-sumut/.[18 March 2021].

[3] Sakinah R, Kusuma HE, Tampubolon AC, Prakarso B. Kriteria Jalur Pedestrian di Indonesia. Jurnal Lingkungan Binaan Indonesia. 2018; 7(2): 81-85.

4] Althoff T, Socic R, et al. Large-scale physical activity data reveal worldwide activity inequality. 2017; Nature 547: 336-339.

[5] Untermann RK. Accomodating the Pedestrian: Adapting Towns \& Neighbourhoods for Walking and Bicycling. New York: Van Nostrand Reinhold Company; 1984.

[6] Shirvani H. The Urban Design Process. New York. VNR Company; 1985.

[7] Iswanto, Danoe. Mengkaji Fungsi Keamanan dan Kenyamanan Bagi Pejalan Kaki di Jalur Pedestrian (Trotoar). Tesis Program Pasca Sarjana Program Studi Magister Teknik Arsitektur Universitas Diponegoro, Semarang; 2006.

[8] Iswanto, Danoe. Pengaruh Elemen-elemen Pelengkap Jalur Pedestrian Terhadap Kenyamanan Pejalan Kaki (Studi Kasus: Penggal Jalan Pandanaran, Dimulai dari Jalan Randusari Hingga Kawasan Tugu Muda). Jurnal Ilmiah Perancangan Kota dan Pemukiman. 2006; 5(1): 21-29.

[9] Rubenstein. Pedestrian Malls Streetscape and Urban Spaces. John Wiley \& Sons, Inc, New York; 1992.

[10] Iswanto, Danoe. Mengkaji Fungsi Keamanan dan Kenyamanan Bagi Pejalan Kaki di Jalur Pedestrian (Trotoar) Jalan Ngesrep Timur V Semarang (Akses Utama Kampus UNDIP Tembalang). Program Pasca Sarjana Magister Teknik Arsitektur Universitas Diponegoro, Semarang; 2003.

[11] Departemen Pekerjaan Umum. Pedoman Perencanaan Jalur Pejalan Kaki pada Jalan Umum. Jakarta Selatan: Direktur Jenderal Bina Marga; 1999.

[12] Purnomo, Andi dkk. Tingkat Kenyamanan Jalur Pedestrian Di Kawasan Simpang Lima Kota Semarang Berdasarkan Persepsi Pengguna. Jurnal Teknik Sipil dan Perencanaan. 2015;17(2): 131136.

[13] Fruin, John. Pedestrian Planning and Design. Metropolitan and Association of Urban Designers and Environmental Planners, Inc, New York; 1979.

[14] Wikipedia. Pendestrian. Available from https://en.wikipedia.org/wiki/Pedestrian. [17 $7^{\text {th }}$ July 2021 ].

[15] Footpath Basic. Available form https://www.itdp.org/2014/03/26/footpath-basics/. [6 $6^{\text {th }}$ Aug ]

[16] Maria.co.id. 7 Syarat Trotoar yang Baik dan Contohnya . Available from https://maria.co.id/syarattrotoar-yang-baik-dan-contohnya/. [22 July 202].

[17] Simantu.pu.go.id.Pedoman Fasilitas Pejalan Kaki. Available from /personal/imgpost/197812092006042004/post/201903131 35241_F_Pedoman_Fasilitas_Pejalan_Kaki.pdf. [26 July]. 